\title{
Preferensi Pemangsaan Drupella sp. pada Jenis Karang yang Berbeda di Perairan Pemuteran, Bali
}

\author{
Ni Wayan Gita Kanela ${ }^{\mathrm{a}}$, IGN Putra Dirgayusa ${ }^{\mathrm{a}}$, dan Widiastuti ${ }^{\mathrm{a}^{*}}$ \\ ${ }^{a}$ Program Studi Ilmu Kelautan, Fakultas Kelautan dan Perikanan, Universitas Udayana, Kampus UNUD Bukit Jimbaran, Bali 80361, Indonesia \\ * Corresponding author email: widiastutikarim@unud.ac.id
}

\section{ARTICLE INFO ABSTRACT}

\section{Article history:}

Received May $18^{\text {th }} 2018$

Received in revised form July $3^{\text {h }} 2018$

Accepted August $21^{\text {th }} 2018$

Available online September $28^{\text {th }} 2018$
Coral reefs has changed over time that are strongly influenced by environmental conditions and human activities. One of the natural damage to coral reefs is corallivorous gastropod such as Drupella sp. The excessive numbers of Drupella sp. cause the coral reef destruction as the average of predation may reach $1.806 \mathrm{~cm}^{2}$ per coral tissues per night per individual. The marine tourism of Pemuteran waters on northern part of Bali Island is rapidly developing. Thus any compromised health of coral reefs could negatively affect this sector such as 2.374 individuals of Drupella sp. found during 2008-2009 according to the Bio-Rock Center. However, this report was not clearly mentioned the method and detail location. Therefore, this study aimed to determine the densitiy of Drupella sp. and prey preferences of Drupella sp. on coral species in Pemuteran waters. There were four observation sites that parallel to the shoreline at similar depths $(5-6 \mathrm{~m})$. The densities of Drupella $\mathrm{sp}$. and prey preference were measured 2 × $20 \mathrm{~m}$ belt transect by using SCUBA. Live coral covers were counted in LIT (Line Intercept Transect) method. The significant difference of Drupella sp. densities among sites was analysed by using one-way ANOVA, while the feeding preference among corals species was identified by using Bonferroni test. The result showed that the highest density of Drupella sp. found at station 1 and the lowest at station 2. It is suggested that related to percentage of live coral cover as the highest was at station 1 and the lowest was at station 2. Studies revealed that Drupella sp. feeding particulary on living coral. Furthermore, our observations indicated that Drupella sp. more attracted to coral Porites and Pocillopora. This feeding preferences are thought to be due to the highest abundance of these corals at all study sites.

2018 JMRT. All rights reserved.

\section{Pendahuluan}

Kondisi terumbu karang di Indonesia pada tahun 2017 menunjukkan kondisi tang bervariasi yaitu sangat baik $6,39 \%$, kondisi baik 23,40\%, cukup 35,06\% dan rusak 35,15\% (Giyanto et al., 2017). Hal tersebut dikarenakan terumbu karang mengalami perubahan yang sangat dinamis dimana perubahannya dari waktu ke waktu sangat dipengaruhi oleh aktivitas manusia seperti penangkapan ikan yang merusak (bom, sianida, jenis alat tangkap yang dilarang pemerintah) dan alami seperti pemutihan karang, dan predasi dari organisme laut seperti gastropoda (Lalang et al.,2013).

Gastropoda dapat menyebabkan kerusakan terumbu karang yang masif. Salah satu spesies gastropoda pemakan polip karang Drupella sp.. Avertabrata tersebut pada kondisi yang ekstrim memberikan dampak yang cukup serius bagi kelangsungan ekosistem karang (Riska et al., 2013), karena memiliki dampak yang serupa dengan predasi bintang laut berduri (Cumming, 2009). Rata-rata laju predasi satu individu Drupella sp. adalah $1.806 \mathrm{~cm}^{2}$ jaringan karang per malamnya (Cumming, 2009) sehingga dapat menyebabkan kematian yang signifikan pada terumbu karang.
Pada umumnya terdapat beberapa faktor yang dapat mempengaruhi keberadaan Drupella sp. pada terumbu karang yaitu kedalaman, substrat dan bentuk pertumbuhan dari karang itu sendiri (Schoepf et al., 2010) dimana Drupella sp. lebih memilih untuk memakan spesies Acropora dengan bentuk pertumbuhan bercabang.

Perairan Pemuteran merupakan salah satu kawasan yang telah mengalami perkembangan pariwisata bahari yang pesat. Hal tersebut dapat dilihat dari semakin meningkatnya perkembangan dive center di wilayah tersebut. Namun keindahan terumbu karang sebagai wisata bahari mengalami berbagai ancaman salah satunya yaitu predasi Drupella sp. Berdasarkan hasil monitoring Bio-Rock Center jumlah Drupella sp. yang berhasil diidentifikasi pada terumbu karang di Perairan ini pada 11 November 2008 hingga awal Juni 2009 ditemukan sebanyak 26.374 ekor (Hutasoit, 2009). Tingginya kelimpahan spesies gastropoda jenis Drupella di terumbu karang Perairan Pemuteran mendorong dilakukannya penelitian ini guna sebagai data acuan untuk mengambil keputusan dalam kegiatan pengelolaan dan pelestarian terumbu karang di Perairan Pemuteran seperti pelarangan penangkapan ikan predator Drupella sp. secara 
berlebih sehingga Drupella sp. tidak melimpah dan merusak terumbu karang.

\section{Metode Penelitian}

\subsection{Waktu dan Lokasi Penelitian}

Pengambilan data Drupella sp. dan terumbu karang dilakukan pada tanggal 21-25 Maret 2018 di perairan Desa Pemuteran, Kecamatan Gerokgak, Kabupaten Buleleng (Gambar 1).

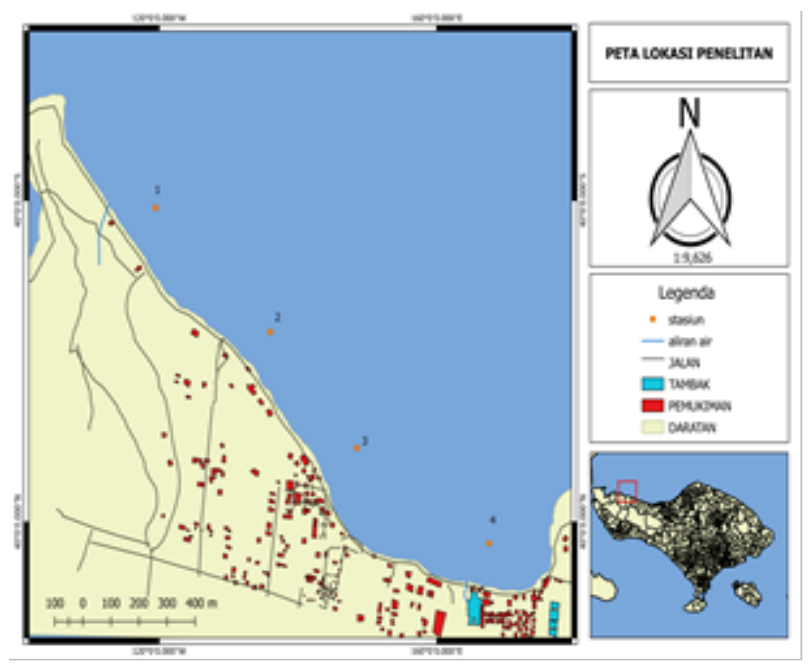

Gambar 1. Peta Lokasi Penelitian

\subsection{Penentuan Stasiun}

Penentuan stasiun pengamatan dilakukan dengan metode purposive sampling. Metode purposive sampling pada penelitian ini dilakukan dengan memilih stasiun penelitian pada titik dengan keadaan pesisirnya berbeda-beda, dimana terdapat 4 stasiun pengamatan (Gambar 2). Stasiun 1 memiliki kondisi pesisir yang masih jarang terdapat kegiatan manusia. Tidak terdapat hotel, restaurant maupun pemukiman penduduk. Stasiun 2 memiliki kondisi pesisir yang mulai ditemukan beberapa pemukiman penduduk. Stasiun 3 merupakan kawasan pesisir yang ramai dengan aktivitas manusia yaitu terdapat pemukiman penduduk yang mulai padat dan terdapat beberapa hotel. Pada stasiun 4 wilayah pesisirnya padat dengan pemukiman penduduk, terdapat beberapa hotel serta tambak penduduk. Penentuan stasiun diawali dengan melakukan pengamatan singkat terhadap kondisi terumbu karang dan pesisirnya. Setiap stasiun terdiri atas 3 kali pengulangan. Stasiun pengamatan sejajar garis pantai pada kedalaman yang sama. Stasiun pengamatan terdapat pada kedalaman yang sama, dari hasil pengambilan data di lapangan diketahui jarak antar stasiun $\pm 500 \mathrm{~m}$. Pengambilan data dilakukan saat keadaan pasang

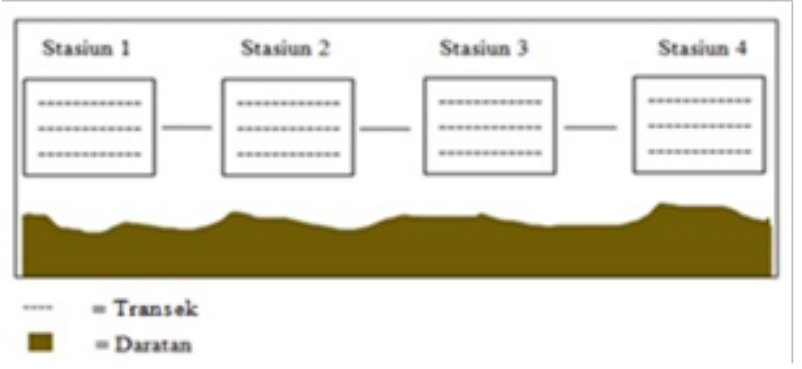

Gambar 2. Skema penentuan stasiun penelitian

\subsection{Kualitas Perairan}

Parameter kualitas perairan yang diukur meliputi suhu, salnitas, kecerahan dan $\mathrm{pH}$. Pengukuran dilakukan pada waktu yang sama dengan pengambilan data di lapangan. Data parameter lingkungan diambil setelah pengamatan sampel Drupella sp. pada setiap stasiun pengamatan. Pengambilan sampel air diambil menggunakan botol selanjutnya diukur segera setelah mencapai perahu atau daratan. Data suhu, salinitas, kecerahan dan $\mathrm{pH}$ pengukuran dilakukan secara insitu

\subsection{Kelimpahan Karang dan Drupella sp.}

Pengambilan data kelimpahan karang dan Drupella sp. menggunakan metode transek sabuk (belt transect). Metode sabuk biasa digunakan untuk mensurvei dampak spesifik terhadap bentik, salah satunya adalah survei terhadap kelimpahan gastropoda (Lalang et al., 2013). Metode transek sabuk juga dapat digunakan untuk mengetahui jumlah koloni dan jumlah jenis karang pada ekosistem terumbu karang (English et al.,1994). Data kelimpahan diambil dengan menggunakan transek sabuk berukuran 2 × $20 \mathrm{~m}$ (Woesik et al., 2009) (Gambar 3). Pada setiap stasiun dilakukan pencatatan genus karang dan jumlah Drupella sp. yang menempel pada karang. Pengamatan dilakukan secara manual di bawah air dan juga dilakukan dokumentasi terhadap objek pengamatan dengan bantuan kamera bawah air.

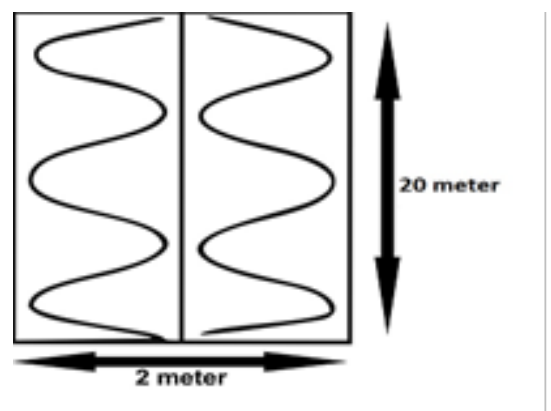

Gambar 3. Metode Transek Sabuk

\subsection{Persen Tutupan Karang}

Pengambilan data terumbu karang mengunakan metode LIT (Line Intercept Transect) dengan pengamatan karang dibatasi pada bentuk pertumbuhan (life form) dan menggunakan peralatan selam scuba dilakukan sepanjang $20 \mathrm{~m}$. Life form karang digunakan untuk melihat pertumbuhan karang hidup dan karang mati pada hamparan yang telah dilakukan pengacakan pada tiap lokasi pengamatan yang ada di dalam kuadrat. Analisis skoring life form merupakan salah satu kriteria yang dipilih sehingga penting identifikasi bentuk pertumbuhan karang. Metode pengamatan ekosistem terumbu karang yang menggunakan transek berupa meteran dengan prinsip pencatatan substrat dasar yang menyinggung transek (Hidayat, 2009).

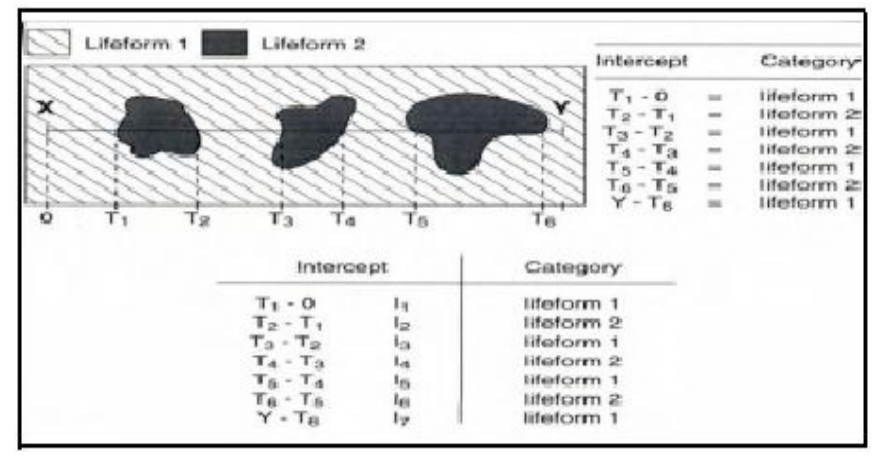

Gambar 4. Metode LIT 


\subsection{Analisis Data}

\subsubsection{Persen Tutupan Karag}

Data yang diperoleh berupa kode-kode life form karang. Analisis persen tutupan karang dilakukan untuk mengetahui kondisi terumbu karang pada tiap tiap stasiun yang selanjutnya dihitung dengan menggunakan rumus (English et al., 1997):

$\mathrm{C}=\frac{\mathrm{a}}{\mathrm{A}} x 100 \%$

Dimana $\mathrm{C}$ adalah persen penutupan life form ke $\mathrm{i}$; a adalah panjang transek lifeform ke i ; A adalah panjang total transek

\subsubsection{Kelimpahan Karang}

Kelimpahan karang pada tiap stasiun pengamatan diolah dengan rumus kelimpahan menurut Brower dan Zar (1997) yaitu dengan rumus sebagai berikut :

$\mathrm{N}=\frac{\mathrm{\Sigma n}}{\mathrm{A}}$

Dimana $\mathrm{N}$ adalah kelimpahan individu $\left(\right.$ koloni $\left./ \mathrm{m}^{2}\right) ; \mathrm{n}$ adalah jumlah individu yang diperoleh tiap stasiun; A adalah luas daerah pengamatan $\left(\mathrm{m}^{2}\right)$

\subsubsection{Kelimpahan Drupella sp.}

Data jumlah individu Drupella sp. pada terumbu karang diolah menjadi data kelimpahan organisme. Kelimpahan menurut Brower dan Zar (1997) yaitu jumlah individu persatuan luas atau volume, dengan rumus sebagai berikut;

$\mathrm{N}=\frac{\mathrm{Zn}}{\mathrm{A}}$

Dimana $\mathrm{N}$ adalah kelimpahan individu (ind $\left./ \mathrm{m}^{2}\right) ; \mathrm{n}$ adalah jumlah individu yang diperoleh tiap stasiun; A adalah luas daerah pengamatan $\left(\mathrm{m}^{2}\right)$

\subsubsection{Preferensi Pemangsaan Drupella sp.}

Analisis data yang digunakan dalam menentukan preferensi jenis karang yang dimangsa Drupella sp. yaitu dilakukan dengan menggunakan rumus ratio pemilihan mangsa (selection ratio) (Manly et al.,1993)

$\omega \mathrm{i}=\frac{\text { oi }}{\text { ail }}$

Dimana $\omega$ adalah Rasio pemilihan mangsa; oi adalah jumlah koloni karang genus i yang terisi Drupella sp.; ai adalah jumlah koloni karang genus $\mathrm{i}$

Uji statistik preferensi pemangsaan menggunakan uji Bonferroni (95\%) mengacu pada Neu et al (1974) dimana apabila hasil uji stasitik diatas nilai interval kepercayaan maka genus karang tersebut diklasifikasikan berpreferensi.

\section{Hasil}

\subsection{Kualitas Perairan}

Suhu di Perairan Pemuteran saat pengambilan data pada stasiun $1,2,3$, dan 4 berkisar antara $28-29{ }^{\circ} \mathrm{C}$. Hasil suhu yang didapatkan pada lokasi penelitian berbeda dengan penelitian sebelumnya. Alif et al (2017) menyebutkan bahwa suhu di Perairan Pemutean berkisar antara $30-31^{\circ} \mathrm{C}$. Suhu yang dibutuhkan untuk pembentukan terumbu karang berkisar antara
25-30 ${ }^{\circ} \mathrm{C}$ (Nontji, 1993). Kisaran suhu yang optimal untuk gastropoda adalah $26-32{ }^{\circ} \mathrm{C}$ (Riska et al., 2013).

Nilai derajat keasaman $(\mathrm{pH})$ pada keempat stasiun berkisar diantara nilai 6-7. Nilai pH pada penelitian Alif et al (2017) di Perairan Pemuteran adalah berkisar antara 6,9-7,5. Zamani dan Maduppa (2011), menyatakan bahwa kisaran nilai pH yang sesuai untuk terumbu karang yaitu 7-8,5. Berdasarkan hasil penelitian nilai $\mathrm{pH}$ pada setiap stasiun pengamatan masih berada pada kisaran normal. Sedangkan hewan gastropoda dapat bertahan hidup pada $\mathrm{pH}$ kisaran 5,7-8,4 (Wijayanti, 2007).

Tabel 1. Parameter kualitas perairan

\begin{tabular}{lcccc}
\hline $\begin{array}{l}\text { Parameter } \\
\text { (satuan ) }\end{array}$ & Stasiun 1 & Stasiun 2 & Stasiun 3 & Stasiun 4 \\
\hline Suhu $\left({ }^{\circ} \mathrm{C}\right)$ & 28 & 28 & 28 & 29 \\
$\mathrm{pH}$ & $6-7$ & $6-7$ & $6-7$ & $6-7$ \\
Kecerahan(\%) & 100 & 80 & 70 & 80 \\
& & & & \\
Salinitas (ppt) & 28 & 28 & 29 & 29
\end{tabular}

Kecerahan perairan di masing-masing stasiun berkisar antara 70-100\%. Kecerahan tertinggi terdapat pada stasiun 1 dan kecerahan terendah terdapat pada stasiun 3 Nilai salinitas pada keempat stasiun tidak memiliki perbedaan nilai yang signifikan yaitu salinitas berkisar antara 28-29 ppt. Salinitas yang didapatkan berbeda dengan hasil penelitian Alif et al (2017) dimana salinitas yang didapatkan pada bulan Mei 2016 yakni berkisar antara 31,25-31,55 ppt. Perbedaan salinitas tersebut terjadi karena pengambilan data pada waktu yang berbeda. Kondisi pengambilan data pada bulan Maret masih dipengaruhi oleh musim hujan, sedangkan pada bulan Mei merupakan musim panas, sehingga salinitas yang didapatkan lebih rendah dari penelitian Alif et al (2017).

Keadaan salinitas berpengaruh pada proses kalsifikasi karang, organisme karang hidup dengan sangat baik pada salinitas $35 \mathrm{ppt}$ atau rata-rata salintas laut samudra. Kisaran salinitas pada umumnya karang dapat hidup pada salinitas antara 27- 40 ppt dan pertumbuhan yang baik yaitu pada kisaran 34-36 ppt (Tarsan, 2016).

\subsection{Kelimpahan Karang}

Kelimpahan karang yang terdapat pada lokasi penelitian didominasi oleh karang genus Porites (Gambar 5). Terdapat 6 jenis karang yang ditemukan pada masing masing stasiun yakni genus Pocillopora, Porites, Acropora, Fungia, Coeloseris dan Goniopora. Sedangkan karang genus Galaxea hanya ditemukan pada stasiun 1 (Gambar 5). Kelimpahan karang di Perairan Pemuteran didominasi oleh karang genus Porites diduga karena karang genus Porites memiliki daya tahan terhadap lingkungan yang memiliki salinitas rendah. Salinitas di Perairan Pemuteran tergolong rendah jika dibandingkan dengan salinitas air laut pada umumnya yang berkisar antara 33-35 ppt (Hutabarat dan Evans,1986). Hal tersebut sesuai dengan pernyataan Tomascik dan Sander, 1985 dalam Latypov, 2003 menyebutkan bahwa komunitas karang masif dari famili Poritiida, Agariciida, dan Faviida yang biasa ditemukan di perairan yang mengalami kekeruhan, eutrofikasi dan bersalinitas rendah. Selain itu, penelitian Munasik dan Rikoh (2011) menunjukkan bahwa komunitas karang keras di perairan Pulau Marabatuan yang keruh dan bersalinitas rendah didominasi karang Porites lutea serta kombinasi kelompok Poritiida lainnya yang mampu beradaptasi 
di lingkungan yang mengalami tekanan kronis, sebagaimana terjadi di perairan Jepara (Munasik et al., 2000) dan Teluk Banten (Meesters et al., 2002). Karang-karang yang dikategorikan sebagai karang resisten terhadap perubahan lingkungan adalah jenis karang masif, mempunyai jaringan yang tebal atau sedikit terintegrasi serta mempunyai pertumbuhan ratarata yang lambat yaitu seperti karang dari genus Porites (McClanahan, 2004).

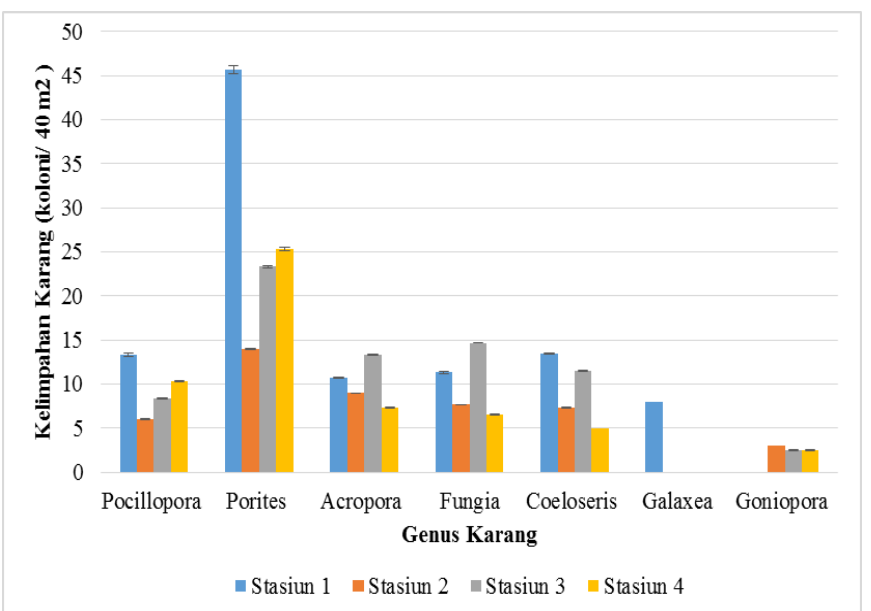

Gambar 5. Kelimpahan karang

Jika dibandingkan dengan karang genus Porites, karang genus Acropora lebih sedikit kelimpahannya. Siringoringo dan Tri (2013) menyebutkan karang genus Acropora merupakan karang yang rapuh dan sangat sensitif terhadap kondisi lingkungan. Kualitas Perairan Pemuteran yang memiliki nilai salinitas yang rendah dan $\mathrm{pH}$ yang berkisar antara 6-7 diduga menjadi faktor penyebab rendahnya jenis karang yang sensitif terhadap kondisi lingkungan seperti karang genus Acropora.

Pada tiap stasiun ditemukan genus Fungia yang memiliki nilai kelimpahan lebih tinggi dibandingkan dengan genus lainnya diduga karena adanya komponen abiotik berupa pecahan karang pada setiap stasiun (Gambar 6). Mampuk et al (2013) menyatakan bahwa habitat utama dari Fungia adalah pada substrat pecahan karang. Mampuk et al (2013) juga menyatakan bahwa keberadaan karang Fungia dalam ekosistem terumbu karang juga dapat memberikan informasi tentang keadaan ekosistem tersebut, dimana jika karang jenis ini melimpah maka mengidentifikasi bahwa ekosistem tersebut sebelumnya mengalami kerusakan.

Karang- karang masif dikatagorikan sebagai karang yang resisten terhadap perubahan lingkungan seperti karang genus Porites, Goniopora, Galaxea dan Pavona (Marshal dan Schuttenberg, 2006). Namun, pada Perairan Pemuteran karang Coeloseris, Goniopora dan Galaxea juga memiliki nilai kelimpahan yang rendah pada tiap stasiunnya dibandingkan dengan karang Porites. Hal ini diduga karena karang Porites memiliki tinggat rekrutmen yang tinggi. Menurut Pitasari dan Aunurohim (2011) dalam Lasano et al (2015) Porites adalah salah satu karang yang bereproduksi dengan cara brooding, dimana larva yang dihasilkan sudah memiliki septa dan alga zooxanthellae yang berkontribusi sebagai penghasil energi bagi larva selama proses penempelan. Selain itu, larva dari mekanisme brooding ini mampu langsung menempel pada substrat, sehingga tingkat rekrutmennya tinggi.

\subsection{Persen Tutupan Karang}

Pada stasiun 1 karang hidup yang umum ditemukan adalah Coral Massive (CM). Persen tutupan karang hidup pada stasiun ini adalah 70\%. Karang mati (Dead Coral dan Dead Coral with algae) memiliki persentase $9 \%$, Persen tutupan karang hidup pada stasiun 1 merupakan persen tutupan tertinggi dibandingkan dengan stasiun lainnya diduga karena wilayah pesisir dari stasiun 1 merupakan wilayah yang masih sepi dari aktivitas manusia sehingga aktivitas darat tidak mempengaruhi perairan dan terumbu karang yang ada pada stasiun 1 .

Persentase karang hidup terendah terdapat di stasiun 2 yaitu $27 \%$ dan didominasi oleh CM. Persentase karang mati di stasiun ini mencapai yakni 31\%. Stasiun 2 merupakan stasiun yang mulai ditemukan beberapa pemukiman penduduk. Stasiun 3 merupakan kawasan pesisir yang ramai dengan aktivitas manusia yaitu terdapat pemukiman penduduk yang mulai padat dan terdapat beberapa hotel. Persentase karang hidup di stasiun 3 dan stasiun 4 juga lebih rendah daripada stasiun 1 yaitu berturut-turut $47 \%$. (persentase karang mati 15\%) dan 31\% (persentase karang mati $29 \%$ ). Stasiun 4 memiliki wilayah pesisir yang padat dengan

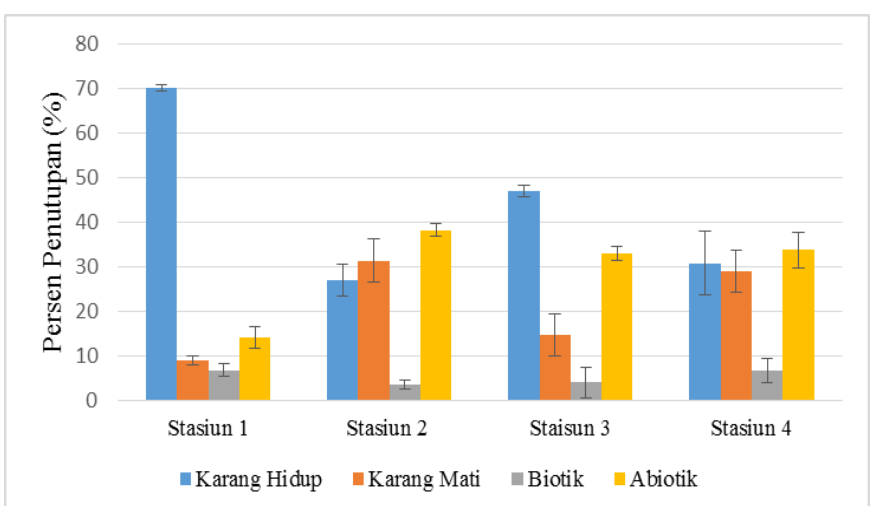

pemukiman penduduk, terdapat beberapa hotel serta tambak penduduk.

Gambar 6 . Persen tutupan karang

\subsection{Kelimpahan Drupella sp.}

Kelimpahan Drupella sp. pada masing-masing stasiun tidak berbeda signifikan (One Way ANOVA p>0,05) (Gambar 7). Kelimpahan tertinggi terdapat pada stasiun 1 yaitu $0,71 \mathrm{ind} / \mathrm{m}^{2}$ dan kelimpahan terendah terdapat pada stasiun 2 yaitu 0,47 ind $/ \mathrm{m}^{2}$.

Kelimpahan Drupella sp. tertinggi terdapat pada stasiun 1 diduga karena persen tutupan karang hidup tertinggi terdapat pada stasiun 1. Sedangkan kelimpahan Drupella sp. terendah terdapat pada stasiun 2 juga dapat disebabkan persen tutupan karang hidup yang rendah. Kelimpahan Drupella sp. pada stasiun 3 dan 4 tidak memiliki nilai yang jauh berbeda. Hasil penelitian The (2016) menyebutkan bahwa lingkungan hidup yang disukai Drupella sp. dewasa adalah pada karang hidup oleh karena itu penutupan karang hidup terkait dengan kepadatan Drupella sp.. Menurut The (2016) pada transek yang memiliki karang hidup yang melimpah, secara simultan jumlah koloni karang yang terisi Drupella sp. juga semakin tinggi. 


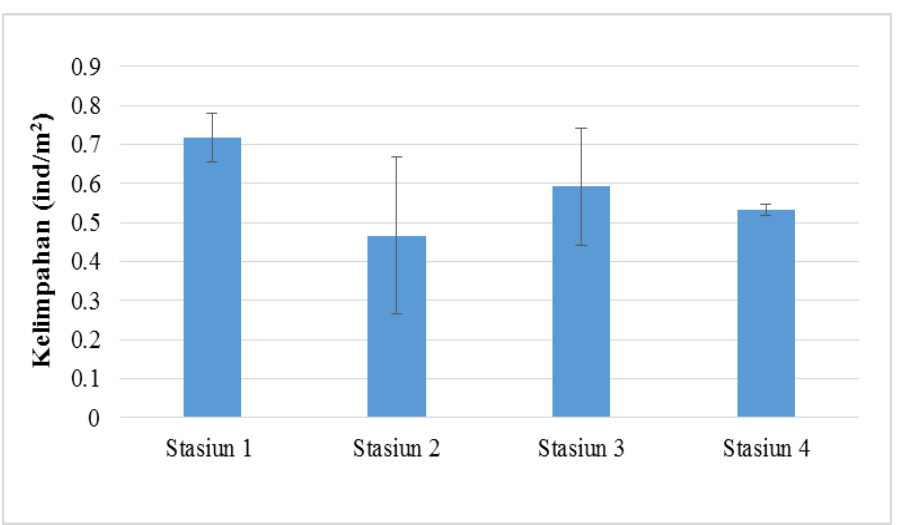

Gambar 7. Kelimpahan Drupella sp.

Hasil kelimpahan Drupella sp. yang didapatkan tergolong sedikit jika dibandingkan dengan penelitian-penelitan sebelumnya. Drupella fragum mewabah di Perairan Jepang dengan kelimpahan hingga 5,12 individu/ $\mathrm{m}^{2}$ (Fujioka and Yamazato, 1983). Ayling (1987) melaporkan bahwa telah terjadi kematian karang dengan $75 \%$ pengurangan persen tutupan karang di terumbu karang Ningaloo yang disebabkan oleh melimpahnya Drupella cornus hingga 19,4 individu/m². Tahun 1990 di Laut Merah, Drupella cornus juga dilaporkan menyebabkan kematian karang dengan kelimpahan hingga 12,24 individu/ $\mathrm{m}^{2}$ (Loya and Gur, 1996 dalam Shafir et al, 2008).

\subsection{Preferensi Pemangsaan Drupella sp.}

Hasil uji stastistik Bonferroni menunjukkan bahwa Drupella sp. memiliki preferensi pada genus karang Porites dan Pocillopora $(\mathrm{p}>0,05)$. Rasio pemilihan mangsa pada stasiun 1 tertinggi terdapat pada genus Pocillopora dan terendah terdapat pada genus Coeloseris. Pada stasiun 2 rasio pemilihan mangsa tertinggi terdapat pada genus Porites dan terendah terdapat pada genus Acropora. Rasio pemilihan mangsa pada stasiun 3 tertinggi terdapat pada genus Pocillopora dan terendah terdapat pada genus Coeloseris. Pada stasiun 4, rasio pemilhan mangsa tertinggi terdapat pada genus Porites dan terendah terdapat pada genus Pocillopora (Gambar 8).

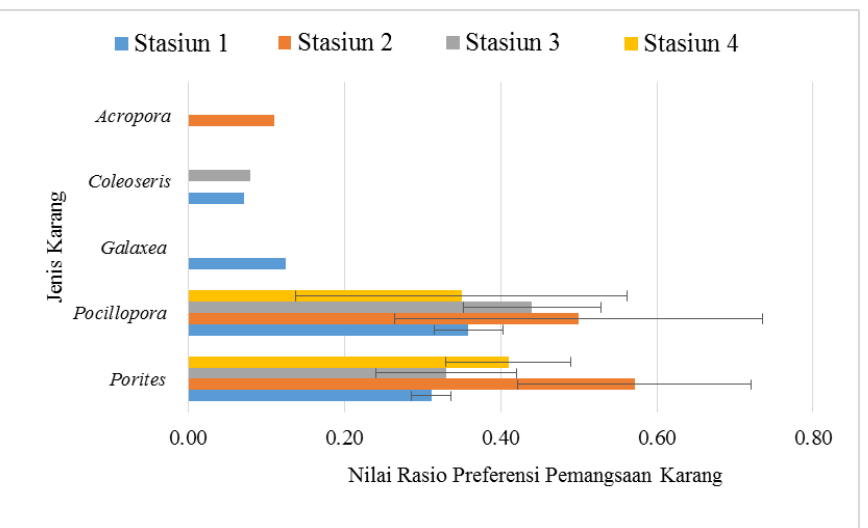

Gambar 8. Preferensi pemangsaan karang

Hasil penelitian ini memiliki hasil yang berbeda jika dibandingkan dengan beberapa penelitian di daerah lain. Hasil studi Schoepf et al (2010) di Perairan Utara Laut Merah dan Hoeksema et al ( 2013) di Koh Tao Thailand pada tahun 20062010. menunjukkan bahwa Drupella sp. memiliki preferensi teradap karang jenis Acropora.

Perbedaan preferensi jenis karang ini diperkirakan disebabkan karena karang Porites memiliki kelimpahan yang paling tinggi di setiap stasiun jika dibandingkan dengan jenis karang lainnya Hal tersebut sesuai dengan pernyataan Schoef et al (2010) yang menyebutkan bahwa Drupella sp. dapat memangsa jenis karang lain apabila karang yang mereka sukai tidak tersedia. Rendahnya jumlah genus Acropora pada keempat stasiun di Perairan Pemuteran menyebabkan Drupella sp. lebih memilih genus Porites.

Pada Perairan Pemuteran Drupella sp. juga memiliki preferensi terhadap karang genus Pocillopora. Karang genus Pocillopora merupakan salah satu genus karang yang disukai oleh Drupella sp. Turner (1994) dalam Hoeksema et al (2013) menyebutkan bahwa Drupella sp. lebih memilih memangsa karang bercabang seperti Acropora, Pocillopora dan Montipora. Pemangsaan Drupella sp. tinggi terhadap jenis karang Pocillopora karena Pocilloporidae memiliki yang tertinggi kandungan protein dan energi dibandingkan genus karang lainnya, seperti Faviidae dan Poritidae (Keesing, 1990).

Hasil penelitian ini menunjukkan bahwa Drupella sp. masih memangsa genus karang yang disukai yaitu karang Pocillopora meskipun Drupella sp. juga memiliki preferensi terhadap karang Porites yang merupakan karang yang mendominasi dan memiliki kelimpahan tertinggi dibandingkan dengan genus karang lainnya.

\section{Simpulan}

Kelimpahan Drupella sp. di perairan Pemuteran tertinggi pada stasiun 1 yakni $0,71 \mathrm{ind} / \mathrm{m}^{2}$ karena pada stasiun ini terdapat persen tutupan karang hidup yang tinggi dan kelimpahan terendah terdapat di stasiun 2 yakni $0,47 \mathrm{ind} / \mathrm{m}^{2}$ karena pada stasiun ini persen tutupan karang hidup rendah dan persen tutupan karang mati tinggi. Drupella sp. memiliki preferensi terhadap genus karang Porites dan Pocillopora. Hal ini menunjukkan bahwa Drupella sp. masih memangsa genus karang yang disukai yaitu karang Pocillopora meskipun juga memangsa genus karang yang memiliki kelimpahan tertinggi di Perairan Pemuteran.

\section{Ucapan Terimakasih}

Penulis mengucapkan terimakasih pada Pande Made Darmawan, Krishna Arisandy dan Nidzar Rafly yang telah membantu menjadi buddy diving.

\section{Daftar Pustaka}

Alif AS, Karang IWGA, Suteja Y.2017.Analisis Hubungan Konsidi Perairan dengan Terumbu Karang di Desa Pemuteran Buleleng Bali. Journal of Marine and Aquatic Sciences 3(2), 142-153.

Ayling AM, Ayling AL. 1987, Ningaloo Marine Park: preliminary fish density assessment and habitat survey, with information on coral damage due to Drupella grazing, Report to the Department of Conservation and Land Management. Western Australia.

Brower JE and JH Zar. 1997. Field and Laboratory Method for General Ecology Wm. C. Brown Company Publisher. America.p 301

Cumming RL. 2009. Populations Outbreaks and Large Aggregations of Drupella on the Great Barrier Reef. Research Publication (Great Barrier Reef Marine Park Authority No.97. 
English S, Wilkinson C, Baker V. 1994. Survey manual for tropical marine resources. Townsville:Australian Institute of Marine Science.

Fujioka Y and Yamazato K.1983. Host selection of Some Okinawan Coral Associated Gastropoda Belonging to Thegenere Drupella,coralliophila, and quoyula. Galaxea 2:5973.

Giyanto et al. 2017.Status Terumbu Karang Indonesia 2017. Core Map-CTI. Jakarta: Pusat Penelitian Oseanografi Lembaga Ilmu Pengetahuan Indonesia

Hoeksema BW, Scott C and True JD. 2013. Dietary shift in corallivorous Drupella snails following a major bleaching event at Koh Tao, Gulf of Thailand. Coral Reefs 1-6.

Hutasoit Pariama.2009. Pemutihan dan Predator Drupella Ancam Terumbu KarangPemuteran. http://www.goblue.or.id/pemutihan-dan-predator-drupellaancam-terumbu-karang-pemuteran. [27 September 2017].

Lalang, Baru Sadarum, La Ode Muh. Yasir Haya, 2013. Kelimpahan Drupella dan Kondisi Terumbu Karang di Perairan Pulau Mandike Selat Tiworo Kabupaten Muna, Sulawesi Tenggara. Jurnal Mina Laut Indonesia Vol.01 No.01. Hal 12-22.

Lasano WF, Fonjtje GK dam Jenny DK. 2015. Distribusi Vertikal Karang Batu (Scleractinia) di Perairan Desa Kalasey Kabupaten Minahasa, Jurnal Pesisir dan Laut Tropis Volume 1 Nomor 1 Tahun 2015.

Latypov Yu Ya. 2003. Reef-building corals and reefs of Vietnam: 2. The Gulf of Tonkin. Russian J. Mar. Biol., 29 (Supl 1): 534-545.

Mampuk, F., Tioho H. dan Kusen, J.D. 2013. Distribusi vertical dan kepadatan karang Fungiidae di perairan Malalayang. Jurnal Pesisir dan Laut Tropis, 1 (1): 42-47.

Manly, BFJ, McDonald LL and Thomas DL.1993.Resource Selection by Animals: Statistical Design and Analysis for Field Studies.Chapman and Hall.London.

Marshall, P. and H. Schuttenberg. 2006. A reef manager's guide to coral bleaching. Great Barrier Reef Marine Park , Townsville. $178 \mathrm{pp}$.

McClanahan, T.R. 2004. The relationship between bleaching and mortality of common corals. Marine Biology, 144: 1239-1245

Meesters, E.H., Nieuwland, G., Duineveld, G.C.A., Kok, A., \& Bak, R.P.M. 2002. RNA/DNA ratios of scleractinian corals suggest acclimatisation/ adaptation in relation to light gradients and turbidity regimes. Mar. Ecol. 227: 233-239.

Munasik, Widjatmoko, W., Soefriyanto, E., \& Sri Sejati. 2000. Struktur Komunitas Karang Hermatipik di Perairan Jepara. Jurnal Ilmu Kelautan, 19:217-224.

Munasik dan Rikoh MS.2011. Struktur Komunitas Karang Keras (Scleractinia) di Perairan Pulau Marabatuan dan Pulau Matasirih, Kalimantan Selatan.Jurnal Ilmu Kelautan Maret 2011.Vol.16 (1) 49-58

Nontji Anugrah.1993. Laut Nusantara. Cetakan Kedua. Jakarta: Djambatan.

Riska, Baru Sadarum, La Ode Muh. Yasir Haya. 2013. Kelimpahan Drupella dan Kondisi Terumbu Karang di Perairan Pulau Mandike Selat Tiworo Kabupaten Muna,
Sulawesi Tenggara. Jurnal Mina Laut Indonesia Vol.02 No.06. Hal 69-80.

Schoepf V, Herler J, Zuschin M. 2010. Microhabitat Use and Prey Selection of the Coral-Feeding Snail Drupella Cornus in the Northern Red Sea. Hydrobiologia 641:45-57.

Shafir S, Gur O, Rinkevich B. 2008. A Drupella cornus outbreak in the northern Gulf of Eilat and changes in coral prey.Coral Reefs 27(2)

Siringoringo RM dan Tri AH. 2013. Kondisi dan Distribudi Karang Batu (Scleractinia corals) di Perairan Bangka. Jurnal Ilmu dan Teknologi Kelautan Tropis Vol 5 No.2 273-285

Tarsan.2016. Laju Predasi Drupella cornus (Roding, 1798) pada Beberapa Jenis Karang Acroposa di Hatchery Pulau Barranglompo. Program Studi Ilmu Kelautan Departemen Ilmu Kelautan Fakultas Kelautan dan Perikanan Universitas Hasanuddin [Skripsi].

The Nguyen Duc.2016.Outbreak of the Coral Eating Snails (Drupella spp) in the Cat Ba World Biosphere Reserve, Vietnam-Looking at The Habitat Utilization and Prey Selection (Scientific Report). Vietnam: UNESCO Young Scienctists Award.

Wijayanti HM. 2007. Kajian Kualitas Perairan di Kota Bandar Lampung Berdasarkan Komunitas Hewan Makrobentos [Tesis]. Semarang.Program pasca Sarjana Universitas Diponegoro.

Woesik, R.V, J.Gilner, Hooten AJ. 2009. Standar Operating Procedure for Repeated Measures of Process and State Variables of Corals Reef Environment. CRTR and Capacity Building for management Program. The University of Quensland. Australia.

Zamani NP, Maddupa H. 2011.A Standard Criteria for Assesing the Health of Coral Reefs: Implication for Management and Conservation. Journal of Indonesia Coral Reefs 1 (2): 137146. 